\title{
Improving Agricultural Sector: The Role of Mudharabah Financing (Study on Sharia Financing Savings and Loans Cooperatives)
}

\author{
Dewi Layyinatus Syifa \\ Universitas Negeri Surabaya, Indonesia \\ email: layyinatus.ls@gmail.com \\ Ahmad Ajib Ridlwan \\ Universitas Negeri Surabaya, Indonesia \\ email: ahmadajibridlwan@unesa.ac.id
}

\begin{abstract}
This study aims to determine the role of mudharabah financing in a Financing Savings and Loan Cooperative towards improving the agricultural sector. Data collection techniques used are observation, interviews, and documentation. The study results indicate that cooperatives play a role in improving the agricultural sector with the help of the capital provided. The increase in the agricultural sector can be seen from the adequacy of capital, increased welfare, and increased labor. However, the improvement of cooperatives' welfare and other factors such as natural weather conditions play a role in improving farmers' welfare. As for the suitability of implementing mudharabah financing in cooperatives, there is still a discrepancy between the implementation and the DSN MUI fatwa No. 7 of 2000 concerning Mudharabah Financing, the capital used by cooperative members is not $100 \%$ of the cooperative. Members also do not get the opportunity to bargain about the amount of profit sharing.
\end{abstract}

Keywords: Sharia Financing Savings and Loans Cooperatives; Mudharabah Financing; Agricultural Sector Improvement

\begin{abstract}
Abstrak: Penelitian ini bertujuan untuk mengetahui peran pembiayaan mudharabah di Koperasi Simpan Pinjam Pembiayaan terhadap peningkatan sektor pertanian. Teknik pengumpulan data yang digunakan ialah observasi, wawancara, dan dokumentasi. Hasil penelitian menyebutkan koperasi berperan dalam meningkatkan sektor pertanian dengan bantuan modal yang diberikan. Adapun peningkatan pada sektor pertanian dapat dilihat dari kecukupan modal, peningkatan kesejahteraan, serta peningkatan tenaga kerja. Akan tetapi, dalam peningkatan kesejahteraan koperasi tidak berperan secara keseluruhan dikarenakan terdapat faktor lain yang dapat mempengaruhi peningkatan kesejahteraan petani yakni kondisi cuaca alam. Sedangkan untuk kesesuaian pelaksanaan pembiayaan mudharabah pada koperasi masih terdapat ketidaksesuaian antara pelaksanaan dengan fatwa DSN MUI No 7 tahun 2000 tentang Pembiayaan Mudharabah, yakni modal yang digunakan
\end{abstract}


Dewi Layyinatus Syifa and Ahmad Ajib Ridlwan

anggota koperasi tidak 100\% dari koperasi, serta anggota juga tidak mendapatkan kesempatan dalam melakukan tawar-menawar mengenai besaran bagi hasil.

Kata Kunci: Koperasi Simpan Pinjam Pembiayaan Syariah (KSPPS); Pembiayaan Mudharabah; Peningkatan Sektor Pertanian 
Improving Agricultural Sector: The Role of ...

\section{Introduction}

Agriculture in Indonesia has an essential role in the economy (Saragih 2017). This sector contributed to the highest employment absorption in Indonesia with 31.86\% (Badan Pusat Statistik 2017) and occupied the prominent employment position in Indonesia in 2017. Apart from being an absorber of labor, the agricultural sector also affected Indonesia's economic growth, as evidenced by the following: The agricultural sector processing industry is the second sector that influences economic growth in Indonesia. On the other hand, the agricultural sector also influences and contributes to people's welfare as a producer of basic needs, affects Indonesia's GDP, and reduces imports from other countries.

The traditional role of the agricultural sector, which is only seen as passive and considered limited to providing and fulfilling food needs in Indonesia, provides a role that is more than it is thought. Based on data obtained from BPS - Statistics Indonesia (2017), 39.68 million Indonesians work as farmers out of a total of 179.13 million Indonesians who fall into the productive category, with many people who depend on the agricultural sector for their livelihood. Agriculture is considered the most crucial sector in the overall economic development.

Agricultural GDP every year tends to continue to increase, as data obtained from Agricultural Statistics (2017) states in 2014, 2015, 2016, and 2017 the following figures were 13.34\%, 13.49\%, 13.45\%, and $13.82 \%$. Although in 2016, agricultural GDP experienced a decline, the average experienced every year consistently increased. It shows that the agricultural sector still has a comparative advantage to continue to be developed so that it becomes a competitive advantage (Nasution 2016).

Although the agricultural sector significantly influences developing the national economy and affects the community's welfare, it also has several obstacles that can hinder its growth (Asaad 2011). Among them, the 
abundance of natural resources owned by the Indonesian state does not make the Indonesian state able to survive and optimize these natural resources. As a result, the imports value from all groups, both raw materials and consumer goods, during January-June 2018 compared to January-June 2017 and 2016 has increased by $21.64 \%, 21.54 \%$, and $31.84 \%$, respectively. According to the Bureau of Budget Analysis and State Budget Implementation, dependence on imports is a recurring problem in the agricultural sector every year, which is ironic as a country with abundant resources must import consumer goods produced in their own country. Another problem that hinders the growth of the agricultural sector is the high rate of crop failure and soaring fertilizer prices (Prasetya and Herianingrum 2016). Finally, the constraint in the agricultural sector, which is quite severe, is capital because capital is the leading and significant internal factor in the implementation of farming (Hadi 2006; Soeleman and Fitria 2020).

Financing is a severe problem in the agricultural sector. Asaad (2011) research stated that capital is the foremost and essential thing in agricultural production besides land. Until now, financing in agriculture is considered less effective due to the additional interest set by the government in return (Nasution 2016). The existence of a fixed interest rate in each financing return makes farmers experience economic difficulties. In the absence of capital, the farmers will find it challenging to increase their productivity. In addition, they will find it difficult to return the financing they have received. The subordinate role of formal financial institutions in providing financing and the difficulty of farmers getting agricultural capital because the agricultural sector has a relatively high risk of crop failure (Ridlwan 2016). Thus, it makes financial institutions consider if they want to provide capital to agriculture.

Therefore, there is a need for alternatives that can help overcome capital constraints in the agricultural sector. The sharia-based financing model is expected to help overcome capital problems in the agricultural sector. Sharia financing is different from the credit system in general, which is a profit- 
sharing system. According to Nasution (2016), profit-sharing is the right concept to be applied to farming communities' economic activities. Businesses in the agricultural sector require a flexible financing model and do not harm either party.

In a cooperative, mudharabah financing exists structurally but is very minimal to use. Even in cooperative institutions, the mudharabah contract is minimal in its use (Susilo and Anam 2018)(Rachdianti, Astuti, and Susilo 2016). For example, the Islamic Savings and Loans El Ram Financing Cooperative is commonly abbreviated as KSPPS El Ram. El Ram Cooperative is a microfinance institution that operates using sharia principles, with various products using sharia contracts according to needs. The mudharabah financing cooperative profile exists and is provided, but due to multiple considerations and risks obtained in the brochure distributed by the product. Therefore, Mudharabah financing is not listed. After reconsideration by looking at the immense opportunities in the following years, the mudharabah financing was re-distributed, even with interested parties.

Many Islamic financial institutions, especially banking in Indonesia, have not answered the problems, especially in the agricultural sector. Based on Islamic banking statistical data dated November 2018, Islamic banking in Indonesia reached around 2,215 distribution of BUS and UUS office networks. Moreover, the fact is that in 2016 the role of Islamic banking in financing the agricultural sector was still deficient, below 4\% (Nasution 2016). As explained above, this is due to the low level of banking confidence in the agricultural sector due to the characteristics of agricultural businesses that have a high risk of crop failure. Therefore, the low contribution of Islamic banking to the agricultural sector makes it increasingly difficult for farmers to obtain capital financing to increase their business. The other difficulty of the agricultural sector in securing financing, apart from having a high risk of crop failure, is the complicated banking administration system that requires equivalent 
guarantees and the lack of public knowledge, and the lack of farmer knowledge of technical banking languages (Muheramtohadi 2017).

Sharia Financing Savings and Loans Cooperatives El-Ram Kembangbahu Lamongan is a financial institution engaged in the savings and loan sector. It offers cooperation with the financing contracts offered are mudharabah, murabahah, ijarah, and multi-service. One of the financing distribution products at Sharia Financing Savings and Loans Cooperatives EL Ram that is often used and widely distributed is financing using mudharabah contracts, most intended for agricultural businesses. Mudharabah financing at Sharia Financing Savings and Loans Cooperatives El Ram is specifically intended to help increase agricultural businesses in the surrounding area. The obstacles cooperatives face to channel financing to the agricultural sector and sharia compliance in the mudharabah financing scheme. This study aims to analyze the role of mudharabah financing on the improvement of the agricultural sector.

\section{Literature review}

\section{Mudharabah financing}

Mudharabah is a sharia contract, a cooperation agreement in providing capital to run a business. According to the agreement, the mudharib gives his capital to sahibul maal to be processed in a profit-sharing business. Therefore, the loss suffered will be borne by the mudharib (investor) as long as the loss is not the negligence of the sahibul maal (Burhanuddin 2013).

The mudharabah financing system is one system that is widely used in productive financing and working capital financing. The profit-sharing distribution in the mudharabah financing system is carried out when the mudarib has carried out a business and knows the profit and loss. So, this system model is considered suitable in the financing model for microenterprises or small and medium-sized enterprises, especially in the 
agricultural sector, by not providing an excessive burden. Heavy on small entrepreneurs so that it is under the characteristics of small communities (Bhakti 2013).

\section{Sharia financing savings and loans cooperatives}

Cooperatives are associations of people who aim to meet the community's economic needs through their business (Burhanuddin 2013). In its implementation, sharia cooperatives must refer to the DSN MUI fatwa, and in each of their activities, they must also avoid usury, maysir, and gharar. The Republic of Indonesia Cooperatives and Small and Medium Enterprises Minister regulation no. 11 of 2018 concerning Cooperative Savings and Loans Business Licensing. Sharia Financing Savings and Loans Cooperatives is a cooperative business unit whose business activities are engaged in loans, financing, and savings by sharia principles: profit sharing and managing zakat, infaq, and waqf (Republik Indonesia 2018).

According to Buchori (2012), the purpose of sharia cooperatives is to promote the economic welfare of members, create justice and increase brotherhood, distribute wealth evenly, according to member contributions, and for social benefit. In addition to having clear goals that are owned and embedded in sharia cooperatives according to Subagyo (2015), the principles of justice, openness and honesty, and the principle of partnership are in addition to having clear goals that are owned and embedded in sharia cooperatives. These three principles must permanently be embedded in the cooperative body because they can be used to carry out the vision and mission of an institution that is following sharia principles and can maintain the community's trust, especially from the cooperative members.

\section{Agricultural sector improvement concept}

The importance of the agricultural sector's role in the continuation of human life makes the agricultural sector need assistance in increasing its 
development, not only in terms of capital but also in terms of human resources. The increase in the agricultural sector can be seen from how farmers obtain much increase in welfare. One of the measuring tools that can find out how much welfare the farmer gets or whether the farmer gets an increase in welfare or not can be seen from the Farmer's Exchange Rate (NTP). In addition, the welfare of farmers can also be observed from how much increase in income they get, whether agricultural productivity has increased, the price of grain is purchased at high prices and the minimum level of crop failure (Keumala and Zainuddin 2018).

In addition to improving welfare, an increase in labor in the agricultural sector is also one of the determining indicators of an increase in the agricultural sector (Maryati 2015). In an agricultural business, it is undeniable that it requires several workers to work on the land, especially when the harvest season arrives. Sometimes even for farmers who have rice fields, the skills in managing the agricultural land are so low that they take the mandated workforce to work the land. Although it looks trivial, these small things can have such a significant impact on other communities.

\section{Methods}

This research was conducted at the Sharia Financing Savings and Loans Cooperative El Ram, located on Jl. The flower of Lopang Mojorayung Lamongan. Sharia Financing Savings and Loans Cooperative El Ram is a microfinance institution that operates using sharia principles and rules, serving since 2008. The El Ram Cooperative is now providing various products to its members in financing distribution and fundraising using various types of contracts by need. The most in-demand product is financing with mudharabah contracts. Mudharabah financing is explicitly channeled for the agricultural sector because mudharabah financing follows the farmers' characteristics with various conveniences in each process. 
The type of research used in this research is descriptive qualitative research. This study aims to find out how the role of mudharabah financing provided by the Sharia Savings and Loans Financing Cooperative El Ram to its members in improving the agricultural sector. This research will be conducted directly on the subject to be studied, using observation and interviews gradually with several informants to obtain the desired data. The informants consisted of 8 people to get the primary data, including three from the cooperative and five from the cooperative members. This study using source triangulation and technical triangulation to validate the data. This study also uses three data analysis techniques, including data reduction, data presentation, and verification.

\section{Result and discussion}

\section{Mudharabah financing practices}

Mudharabah financing at the El Ram cooperative is financing intended for agricultural businesses. It is also seasonal financing, where the payment of profit-sharing installments is carried out every month, while the principal installments are paid when they fall due. The benefit of this financing is that it can meet the capital of a business, mainly seasonal businesses such as agricultural businesses.

The term of mudharabah financing installments at El Ram Cooperative is a maximum of 2 years, with a maximum financing application ceiling of Rp10,000,000-. Customers must complete data requirements when applying for mudharabah financing at El Ram Cooperative. The data are a photocopy of the husband's and wife's ID cards, a photocopy of the card family, filling out the application form, having a guarantee or collateral, opening a membership account, and being willing to be surveyed. To get Rp500,000 - Rp1,000,000, the customer must submit a photocopy of the husband and wife's ID card and a photocopy of a valid family card. To get Rp 1.000 .000 - Rp5,000,000, the customer must submit a photocopy of the husband and wife's ID card, a valid 
family card, and guarantee data. To get Rp5,000,000 - Rp10,000,000, the customer must submit the same documents to get Rp 1.000.000 Rp5,000,000 and an additional photocopy of the Bank or Baitul Maal wa Tamwil account's book for the last three months.

\section{The role of el ram cooperative in improving the agricultural sector with mudharabah financing}

Mudharabah financing provided by the Sharia Savings and Loans Financing Cooperative El Ram has shown its role to help increase microenterprises, especially in the rice and corn agricultural sectors. Cooperative efforts in improving micro-enterprises in the agricultural sector are carried out by providing business capital to farmers to support agricultural businesses, as Mr. Riyadi (chairman of the cooperative) said.

"I think we can help and provide capital to its members to help improve their business. We provide top service. The services we provide are in the form of savings and financing distribution. For members who need a place to store their money, we provide various kinds of savings, while for members who require funds for business development, we also provide them." (Results of an interview with Mr. Riyadi on March 27, 2019).

Mudharabah financing is a product that is identical to profit sharing according to the main characteristics of Islamic banking (Saifidin 2020). Each of its members has felt the financing provided by El Ram Cooperative to its members by delivering agricultural business capital to support improvements in agricultural businesses. The capital obtained by cooperative members who are also farmers can meet all the needs of agricultural businesses. However, even though farmers' efforts in developing their agricultural businesses have been maximized, the existence of uncertain natural conditions and changes over time can also be a barrier for farmers to maximize their agricultural output. 
The role of the El Ram cooperative in helping to increase the business of the agricultural sector for cooperative members who are also a farmer is only limited to provide capital without any coaching guidance. It is not in line with Anggraeni and Dwi's (2013) research, which states that coaching is indispensable in developing a business. It is a form of empowerment of cooperatives in encouraging members who receive mudharabah financing to improve the business's quality. The provision of mudharabah financing to members of El Ram Cooperative plays a role in improving the agricultural sector, which can be seen from several indicators.

\section{Capital adequacy}

The provision of capital in the form of mudharabah financing that has been distributed to cooperative members has played a role in the process of increasing agricultural business. Although the El Ram cooperative does not provide unique guidance to members who receive mudharabah financing, El Ram KSPPS has played a crucial role in growing business in the agricultural sector. The fulfillment can see of the capital needed by farmers running their business. The results of an interview with Mrs. Umami, a cooperative member, stated that mudharabah financing at the El Ram cooperative could help meet agricultural capital needs as follows.

"Oh, very fulfilling. Because I can go back to planting, I can buy superior seeds and needed fertilizers and pest medicines. The result is the harvest. Alhamdulillah, the harvest is good. Because the seeds are superior, fertilizers and pest medicines must be given on schedule." (Result of an interview with a farmer, mudharabah financing recipient, Wednesday, April 03, 2019).

There is an increase in business income, business productivity, farmers' welfare, and a reduction in unemployment or an increase in the workforce. As research by Lindiawatie and Shahreza (2018), the role of sharia cooperatives and BMTs are fostering and providing benefits for the benefit and improving the welfare and members of the community. 
No matter how small a business is, it will not run if its capital cannot meet its needs. The fulfillment of business capital provided by El Ram Cooperative in the form of mudharabah financing for cooperative members who are also farmers has been more effortless for the cooperative members in running their businesses and develop their agricultural businesses. The research results conducted by Prasetya and Herianingrum (2016) state that mudharabah financing plays a significant role in providing financing distribution to the agricultural sector and by the characteristics of the agricultural sector. The sufficient capital provided by El Ram Cooperative in helping to meet the needs of members' agricultural businesses can be proven by the ability of cooperative members who are also farmers to return to planting.

\section{Welfare improvement}

The provision of mudharabah financing helps fulfill capital adequacy and is also expected to improve the welfare of its members. Therefore, Mudharabah financing capital provided by El Ram Cooperative to its members plays an essential and influential role in increasing its members' agricultural business and improving the welfare of members who receive mudharabah financing.

The welfare of farmers can be measured from several things, including through the Farmer's Exchange Rate, how much income the farmers get, and how much the increase in the farmers' productivity. Prastiani \& Indra (2014) states that Islamic financing plays a role and affects increasing customer welfare. From the mudharabah financing provided by El Ram Cooperatives to its members, it is known that this mudharabah financing assistance can provide welfare for each member. As evidenced, the cooperative members who are also farmers able to fulfill their daily needs and at the same time send their children to school to support education to a higher level. 
Sufficient working capital needed will have an impact on increasing business income. Increased income indicates that a business is also growing. Getting mudharabah financing distributed by El Ram Cooperative to cooperative members who are farmers can help increase income. The average monthly income of cooperative members has increased. The increase in the income of cooperative members after receiving financing from cooperatives is in line with research conducted by Kuraohman (2017) that mudharabah financing facilitates the community's economy, which is marked by an increase in member income after receiving financing.

Adequacy of capital followed by an increase in the income of a business is also inseparable from an increase in business productivity. As the business develops, the products produced also increase, especially if the required capital and supportive natural conditions are sufficient. It is different from Prastiawati and Darma's (2016) research, which shows that financing from Baitul Maal wat Tamwil (BMT) does not affect members' business development because business development is based on market demand. The success of the agricultural business is based on natural conditions.

The productive financing provided by El Ram Cooperative to its members who are also farmers in the form of mudharabah financing has played an important and influential role in developing agricultural businesses. According to Hidayatulloh and Hapsari's (2015) research, the increasing welfare of BMT members is influenced by productive financing provided by BMT through sharia maqashid. Therefore, with an increase in business and an increase in income, it will affect the welfare of members.

Islam also teaches creatures to work to meet their needs continually. Because to achieve true prosperity, Allah SWT commands his creatures to work to get pleasure from Him, as stated in Qs. At Taubah verse (24). 


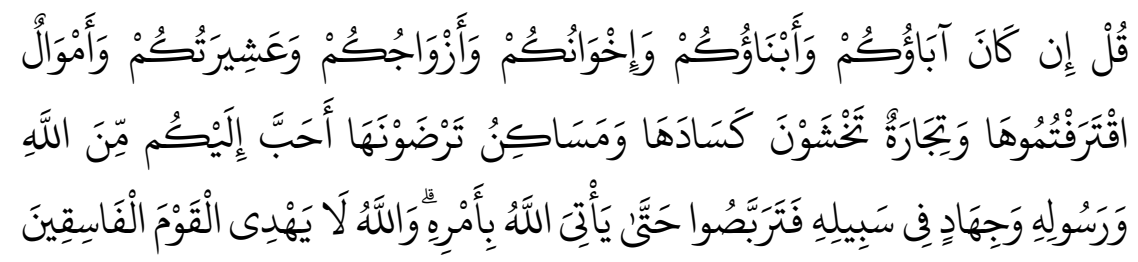

24. Say, [O Muhammad], "If your fathers, your sons, your brothers, your wives, your relatives, wealth which you have obtained, commerce wherein you fear decline, and dwellings with which you are pleased are more beloved to you than Allah and His Messenger and jihad in His cause, then wait until Allah executes His command. And Allah does not guide the defiantly disobedient people."

\section{Workforce improvement}

The increase in employment and the reduction in the unemployment rate in Indonesia are influenced by the agricultural sector. The increasing number of cooperative members' agricultural businesses due to obtaining mudharabah financing from cooperatives absorbs much labor to help reduce unemployment in Indonesia due to the high productivity produced. Every process in agriculture, both during planting and harvesting, requires much labor. Because the more extensive the agricultural land owned and the more productivity produced, the more labor is needed, even though this happens only during the harvest and planting periods. In contrast, during the processing period, it is processed personally as the landowner. By Arianto's (2011) research, mudharabah financing is productive financing. Therefore, it plays a role in empowering the economy of small communities through microenterprises, and with this mudharabah financing is one way to create jobs that can also increase income. 
Improving Agricultural Sector: The Role of ...

\section{Barriers faced by cooperatives in distributing financing for agricultural business}

The financing products provided by El Ram Cooperative to its members who are also farmers affect the improvement of the agricultural sector. However, providing the distribution of mudharabah financing to its members is not always smooth without any obstacles. In distributing mudharabah financing products, El Ram Cooperative encountered several obstacles that could hinder the process of distributing mudharabah financing, one of which was due to the vulnerability of agricultural businesses to crop failure and pest attacks. Because farmers who experience crop failure will automatically experience losses, and there is no cost to pay the financing installments every month, the money is used for other needs. It is supported by Mr. Riyadi's (cooperative chairman) statement.

"As for the challenge, when the farmer experiences crop failure, that is where our challenge is. His name is also a farmer. It is difficult to predict because the current natural weather is also often erratic. If they do not have a side business or a side job, it will be a little tricky (Results of an interview with Mr. Riyadi on March 27, 2019).

In addition to crop failure, another problem that becomes an obstacle in distributing mudharabah financing is unpredictable weather conditions. Uncertain weather conditions can also cause agricultural businesses that have been optimally managed to fail. It supports Ruminta (2016), which states that climate change in agricultural businesses significantly affects the sustainability of crop yields. The shift of the rainy season makes the period of cropping shifts, and floods and droughts cause crop failure. When the rainy season arrives, agricultural yields are relatively increased, but the selling price of grain has decreased due to the condition of the grain is not optimally dry. Meanwhile, the yields obtained been reduced during the dry season, but the selling price of grain increased.

Economica: Jurnal Ekonomi Islam - Volume 12, Nomor 1 (2021) 


\section{The suitability of the sharia financing scheme implemented by el ram cooperative in the agricultural sector}

The suitability of the mudharabah financing implementation in El Ram Cooperative for the agricultural sector against sharia provisions can be seen from practice suitability. It also can be seen from how El Ram Cooperative fulfills the requirements and pillars of mudharabah financing, which are the existence of shahibul maal and mudharib, a statement of consent qabul, and the presence of capital and business. Following the Fatwa of the National Sharia Council No: 07/DSN-MUI/IV/2000 concerning mudharabah financing, the pillars of mudharabah are providers of funds and recipients of funds statements qabul consent, capital, profit sharing, and business activities. As mudharabah requirements, the mudharib and shahibul maal must be legally competent. There is a statement of consent from both parties, the existence of an agricultural business run by the mudharib. The capital given equals the total business capital needed by the mudharib, the profit, and the shareholder. Both parties agree upon the results so that the implementation of mudharabah financing at KSPPS El Ram is per the DSN MUI fatwa No. 7 of 2000 (Dewan Syariah Nasional Majelis Ulama Indonesia 2000).

However, the capital provided by the cooperative to members of the mudharabah financing recipient who is also a farmer has not $100 \%$ met the specified criteria. The capital value should be all the capital needed by farmers, but the capital obtained is only as additional capital in practice, likewise with profits or profit-sharing. El Ram Cooperative has determined the amount of profit-sharing on mudharabah and mudharib financing as cooperative provisions. In mudharabah financing, there should be an agreement between both parties or a bargain on profit-sharing, but it is not implemented in practice at El Ram Cooperative. Therefore, Mudharib does not get the opportunity to bargain to determine the amount of profit sharing. 
Improving Agricultural Sector: The Role of ...

\section{Conclusion}

Based on the results of research that has been carried out at El Ram Cooperative on the role of mudharabah financing distributed, it can be concluded that cooperatives play a role in helping to improve the agricultural sector with mudharabah financing distributed to their members. Mudharabah financing provided can assist in meeting capital needs even without unique guidance. It also affects the welfare of members, which can be seen from the farmer exchange rate, which can be realized by increasing income and business productivity and having an effect on increasing the workforce.

El Ram Cooperative's obstacles in distributing mudharabah financing to farmers are the high rate of crop failure and unpredictable natural weather conditions that make crop yields uncertain. In addition, farmers' incomes are obtained not every month but every month for three months. So that makes members will have difficulty in paying installments per month. Then the mudharabah financing provided by El Ram Cooperative to its members who are also farmers has been running as it should because El Ram Cooperative has met the requirements and pillars of mudharabah financing. However, some discrepancies exist in some of the mudharabah financing requirements implemented by El Ram Cooperative, which determines profit-sharing. For example, the determination of profit-sharing is only determined unilaterally by the cooperative without any bargaining with members. In addition, the capital provided by the cooperative is not $100 \%$ capital used by the mudharabah financing recipient in increasing their business, but only as additional capital.

\section{References}

Anggraeni, Feni Dwi. 2013. "Pengembangan Usaha Mikro, Kecil Dan Menengah (UMKM) Melalui Fasilitasi Pihak Eksternal Dan Potensi Internal (Studi Kasus Pada Kelompok Usaha 'Emping Jagung' Di Kelurahan Pandanwangi Kecamatan Blimbing Kota Malang)." Jurnal

Economica: Jurnal Ekonomi Islam - Volume 12, Nomor 1 (2021)

https://journal.walisongo.ac.id/index.php/economica 
$\begin{array}{lllll}\text { Administrasi } & \text { Publik } & 1 & \text { (6): }\end{array}$ http://administrasipublik.studentjournal.ub.ac.id/index.php/jap/article /view/195.

Arianto, Dwi Agung Nugroho. 2012. "Peranan Al-Mudharabah Sebagai Salah Satu Produk Perbankan Syariah Dalam Upaya Mengentaskan Kemiskinan Di Indonesia." Jurnal Ekonomi Dan Pendidikan 8 (2): 164-85. https://doi.org/10.21831/jep.v8i2.794.

Asaad, Mhd. 2011. "Peningkatan Peranan Perbankan Syariah Untuk Pembiayaan Usaha Pertanian." MIQOT: Jurnal Ilmu-Ilmu Keislaman 35 (1): 113-27. https://doi.org/10.30821/miqot.v35i1.134.

Badan Pusat Statistik. 2017. "Jumlah Lapangan Pekerjaan Menurut Lapangan Pekerjaan Utama Di Indonesia Tahun 2017."

Bhakti, Rizki. 2013. "Pemberdayaan UMKM Melalui Pembiayaan Dengan Prinsip Bagi Hasil Oleh Lembaga Keuangan Syariah." Arena Hukum 6 (1): 121-37. https://doi.org/10.21776/ub.arenahukum.2013.00601.7.

Buchori, Nur Syamsudin. 2012. Koperasi Syariah Teori Dan Praktik. Banten: Pustaka Aufa Media.

Burhanuddin. 2013. Koperasi Syariah Dan Pengaturanya Di Indonesia. Edited by Musleh Herry and Muhammad Idris. 2nd ed. Malang: UIN MALIKI MALANG.

Dewan Syariah Nasional Majelis Ulama Indonesia. 2000. Fatwa Dewan Syariah Nasional No: 07/DSN-MUI/IV/2000 Tentang Pembiayaan Mudharabah (Qiradh). Indonesia.

Hadi, Sutrisno. 2006. Statistik Jilid 2. Edited by Andi. 1st ed. Yogyakarta: Yayasam Penerbitan Fak. Psikologi UGM.

Hidayatulloh, Muhammad, and Meri Indri Hapsari. 2015. "Peran Pembiayaan Produktif BMT Mandiri Mulia Terhadap Peningkatan Kesejahteraan Anggota Perspektif Maqasih Syariah." Jurnal Ekonomi Syariah Teori Dan Terapan 2 (10): 797. https://doi.org/10.20473/vol2iss201510pp797811.

Keumala, Cut Muftia, and Zamzami Zainuddin. 2018. "Indikator Kesejahteraan Petani Melalui Nilai Tukar Petani (NTP) Dan Pembiayaan Syariah Sebagai Solusi." Economica: Jurnal Ekonomi Islam 9 (1): 129-49. https://doi.org/10.21580/economica.2018.9.1.2108. 
Improving Agricultural Sector: The Role of ...

Kuraohman, Nanang Taufiq. 2017. "Peningkatan Pendapatan Nasabah Dalam Memanfaatkan Pembiayaan Mudharabah (Studi Pada BMT Nur Insan Mandiri Sukoharjo)." NAskah Publikasi Ilmiah, 1-12.

Lindiawatie, and Dhona Shahreza. 2018. "Peran Koperasi Syariah BMT Bumi Dalam Meningkatkan Kualitas Usaha Mikro." AL URBAN 2 (1): 1-12. https://doi.org/10.22236/alurban_vol2/is1pp1-12.

Maryati, Sri. 2015. "Peran Bank Pembiayaan Rakyat Syariah Dalam Pengembangan UMKM Dan Agribisnis Pedesaan Di Sumatera Barat." Economica $\quad 3 \quad$ (1): $1-17$. https://doi.org/10.22202/economica.2014.v3.i1.231.

Muheramtohadi, Singgih. 2017. "Peran Lembaga Keuangan Syariah Dalam Pemberdayaan UMKM Di Indonesia." Muqtasid: Jurnal Ekonomi Dan $\begin{array}{lllll}\text { Perbankan } & \text { Syariah } & 8 & \text { (1): }\end{array}$ https://doi.org/10.18326/muqtasid.v8i1.65-77.

Nasution, Zubaidah. 2016. "Model Pembiayaan Syariah Untuk Sektor Pertanian." Ekonomi Dan Perbankan Syariah 3 (2): 325-43. https://doi.org/10.21107/dinar.v3i2.2701.

Prasetya, Renata Agung, and Sri Herianingrum. 2016. "Peranan Baitul Maal Wa Tamwil Meningkatkan Usaha Mikro Melalui Pembiayaan Mudharabah." Jurnal Syarikah: Jurnal Ekonomi Islam 2 (2): 252-67. https://doi.org/10.30997/jsei.v2i2.286.

Prastiani, Siti Chaerunisa, and Jasmi Indra. 2014. "Peranan Pembiayaan Syariah Terhadap Peningkatan Kesejahteraan Nasabah Pada BMT Berkah Mentari Pamulang." Ilmiah Akuntansi 2 (3): 343-60.

Prastiawati, Fitriani, and Emile Satya Darma. 2016. "Peran Pembiayaan Baitul Maal Wat Tamwil Terhadap Perkembangan Usaha Dan Peningkatan Kesejahteraan Anggotanya Dari Sektor Mikro Pedagang Pasar Tradisional." Jurnal Akuntansi Dan Investasi 17 (2): 197-208. https://doi.org/10.18196/jai.2016.0055.197-208.

Rachdianti, Tania, Endang Siti Astuti, and Heru Susilo. 2016. "Pengaruh Penggunaan E-Tax Terhadap Kepatuhan Wajib Pajak (Studi Pada Wajib Pajak Terdaftar Di Dinas Pendapatan Daerah Kota Malang)." Jurnal Perpajakan (JEJAK)/.Vol.11.

Economica: Jurnal Ekonomi Islam - Volume 12, Nomor 1 (2021)

https://journal.walisongo.ac.id/index.php/economica 
Republik Indonesia. 2018. Peraturan Menteri Koperasi Dan Usaha Kecil Dan Menengah Republik Indonesia No. 11 Tahun 2018 Tentang Perizinan Usaha Simpan Pinjam Koperasi. Indonesia.

Ridlwan, Ahmad Ajib. 2016. "Implementasi Akad Muzara'ah Pada Bank Syariah: Alternatif Akses Permodalan Sektor Pertanian." Iqtishoduna 5 (1):

34-48. https://ejournal.iaisyarifuddin.ac.id/index.php/iqtishoduna/article/vie $\mathrm{w} / 82$.

Ruminta, Ruminta. 2016. "Analisis Penurunan Produksi Tanaman Padi Akibat Perubahan Iklim Di Kabupaten Bandung Jawa Barat." Kultivasi 15 (1): 37-45. https://doi.org/10.24198/kultivasi.v15i1.12006.

Saifidin, Muhamad. 2020. "Pros and Cons of Implementing Mudharabah Agreement for Agricultural Financing with the Implementation of Maqosid Sharia (Case Study of the Implementation of the Mudhorobah Agricultural Agreement in Tamzis KPPS)." Journal of Islamic Business and Economic Review (JIBER) 3 (1): 14-22. https://stebilampung.ac.id/journal/index.php/jiber/article/view/110.

Saragih, Faoeza Hafiz. 2017. "Pembiayaan Syariah Sektor Pertanian." Jurnal Agrica 10 (2): 112. https://doi.org/10.31289/agrica.v10i2.1458.

Soeleman, Sugiharto, and Gita Fitria. 2020. "Biological Assets as MudharabahBased Loan Collateral for Smallholder Farmers In Indonesia: A Feasibility Study." Diponegoro International Journal of Business 3 (1): 61-67. https://doi.org/10.14710/dijb.3.1.2020.61-67.

Subagyo, Ahmad. 2015. Keuangan Mikro Syariah. 1sted. Jakarta: Mitra Wacana Media.

Susilo, Edi, and A. Khoirul Anam. 2018. "Sharia Complience Akad Berbasis Natural Uncertainty Contract (NUC) Lembaga Keuangan Mikro Syariah Di Kabupaten Jepara." Al-Uqud: Journal of Islamic Economics 2 (1): 20. https://doi.org/10.26740/al-uqud.v2n1.p20-37. 